\title{
In Memory of Marina Blagojević Hughson (February 5, 1958 - June 6, 2020)
}

\section{"You wanted to interview yourself. Why?}

There are many reasons. First of all, I am an experienced researcher and I understand well the power of the one who shapes questions and gives an implicit interpretative framework. Second, the envisaged scope for my life story is simply not sufficient, and my life cannot be easily formatted using general questions. I want to tell my life story when, how, and how much I want and how much I believe it to be good and necessary. My life has had a matrix too complex to be reduced or placed into a simple and trivial, most often chronological, course of events. Instead of having someone who does not know me ask me questions that are some kind of general points, I want to talk about myself primarily in order to convey a message. So, this is not about a simple process of reconstructing events and facts, but about my intention to say what I believe to be important and what makes up just one of many "red threads" in my life. The risk of inadequate questions is very big and I keep reassuring myself of this time and again.

As early as the mid-1990s, I decided to speak in public only when I want to convey a message, and not when others think it is 'convenient' to fit me into their framework. I have absolutely no desire to become a 'public person' by constantly appearing in the media, or by accumulating insignificant functions or positions. I gave up the idea that it makes sense to present 'one's story' to a broad circle of listeners because I believe that the circle of those being merely able to understand and follow what I am doing and dealing with is greatly narrowing. The hyperinflation of information and superficial interpretations in the field I deal with essentially reduces comprehensibility because it suspends depth. And the one and only thing I care about is depth, because I believe that the only way to understand the surface is from depth. And the more I penetrate into depth, owing to my serious and hard work and reflection, the more difficult it becomes for me to communicate and for my listeners to understand what I am saying. Therefore, quite deliberately and with forethought, I altered my strategy. I say only what and how much I want to say, and I am solely engaged in a dialogue with myself because I respect myself as a reflexive and auto-reflexive subject." (Interview with Marina Blagojević Hughson). ${ }^{1}$

That was Marina Blagojević Hughson herself-a renowned sociologist, demographer, and feminist; a women's studies, gender studies, and masculinity studies expert-who always stood out. More than that is told by her enviable and extensive professional biography and bibliography. ${ }^{2}$ 
Beyond her scholarly acclaim, Marina was also a wonderful person, and that is why I must talk about her only in personal terms. I met Marina in October 1992 in the Centre for Women's Studies at the Institute for Cultural Development in Belgrade, Serbia. What I am referring to is that beautiful building on Rige od Fere Street in whose inner yard grows (or at least back then grew) a vine, which, in October, becomes heavy with dark blue grapes.

The first characteristic you would notice about Marina, apart from her impressive beauty, was her cleverness. The intelligence with which she explained phenomena around us, her perception and reading of details, the connection of apparently remote things - all of which she did with ease, clearly and convincingly, whether it was life or science she dealt with. I was always fascinated by how she unpacked and explained supposedly common elements of reality in her analyses, how she shed light on their hidden meaning. Everything obtained new and more convincing significance owing to the facts that she devotedly worked to discover and systematize. One of the first of Marina's books I read was Žene izvan kruga (Women outside the circle), ${ }^{3}$ whose perfectly written preface I can still remember - it seemed so simple at first glance and yet it was so eloquent in terms of both everyday life and science. A similar case can be seen in another of her books, Roditeljstvo $i$ fertilitet (Parenthood and fertility), ${ }^{4}$ where she deals with the concept of micro-matriarchy, the sacrificial position of women during the hard 1990s. In "transition," she argues, women have the role of the "family pillar" which not only subverts but also maintains the "macro-patriarchy." After this came two edited volumes-Mapiranje mizoginije I i II (Mapping misogyny I and II) $)^{5}$ - significant publications for feminist scholarship and on a much broader scale as well. It was then that she began to work on a book of articles dealing with women's organizations during the 1990s, as well as an essay on body and corporality, which became especially dear to me. Of course, I cannot enumerate here all the elements of her enviable and extensive bibliography, nor am I aiming at that. Rather, I wish to highlight the inspiration of her works and her example. From her I developed the idea to found the Informative-Documentary (INDOC) Centre; ${ }^{6}$ from her I heard of the idea of "semi-periphery" as applied to our reality, which deeply inspired me. Indeed, only a few hours before I received the sad news of her passing, I held her book Sutra je bilo juče (Tomorrow was yesterday), ${ }^{7}$ thinking what a wonderful title that is. And, by coincidence, I thought again about her concept of supra-disciplinarity which, so typically of Marina, is supposed to expand the insights of science even into issues that traditionally do not belong to it. As she asserted, "Gender studies are multidisciplinary, interdisciplinary, transdisciplinary, and supra-disciplinary, which means that they go beyond science and its disciplines and involve various types of knowledge, from the everyday skills all the way to philosophical and even spiritual meanings. From multidisciplinarity, via interdisciplinarity, transdisciplinarity, all the way to supradisciplinarity, the level of exchange among disciplines and knowledge fields is intensified and new, opening broader perspectives." 8

Marina did not care about disciplinary boundaries or even any other kinds of boundaries. In all she did, she was brave and energetic - and warm, frank. In memory of her professor Anđelka Milić, she founded a prestigious prize; she also founded the SEFEM. ${ }^{9}$ We worked together on the establishment of IRIS, an interdisciplinary doc- 
toral program for gender studies. Every one of her texts, no matter how scientific, was always to a large extent also literary, always a good piece of literature. Every one of her works contained as its basis a dream and a perfect capability of realization. Every meeting with her was both fun and encouraging. She was, before anything else, full of incredible energy, lucid, and optimistic, as inspired as well-organized and rational, a volcanic combination of sincerity, openness, intellectual and human honesty, sense of humour, hedonism. If the first law of thermodynamics, which states that the total amount of energy always remains the same, is still valid, then I must wonder where all this mighty fire went so suddenly and so early, much too early.

Biljana Dojčinović, University of Belgrade, Serbia (translated by Goran Petrović)

All photos courtesy of John Ewing Hughson

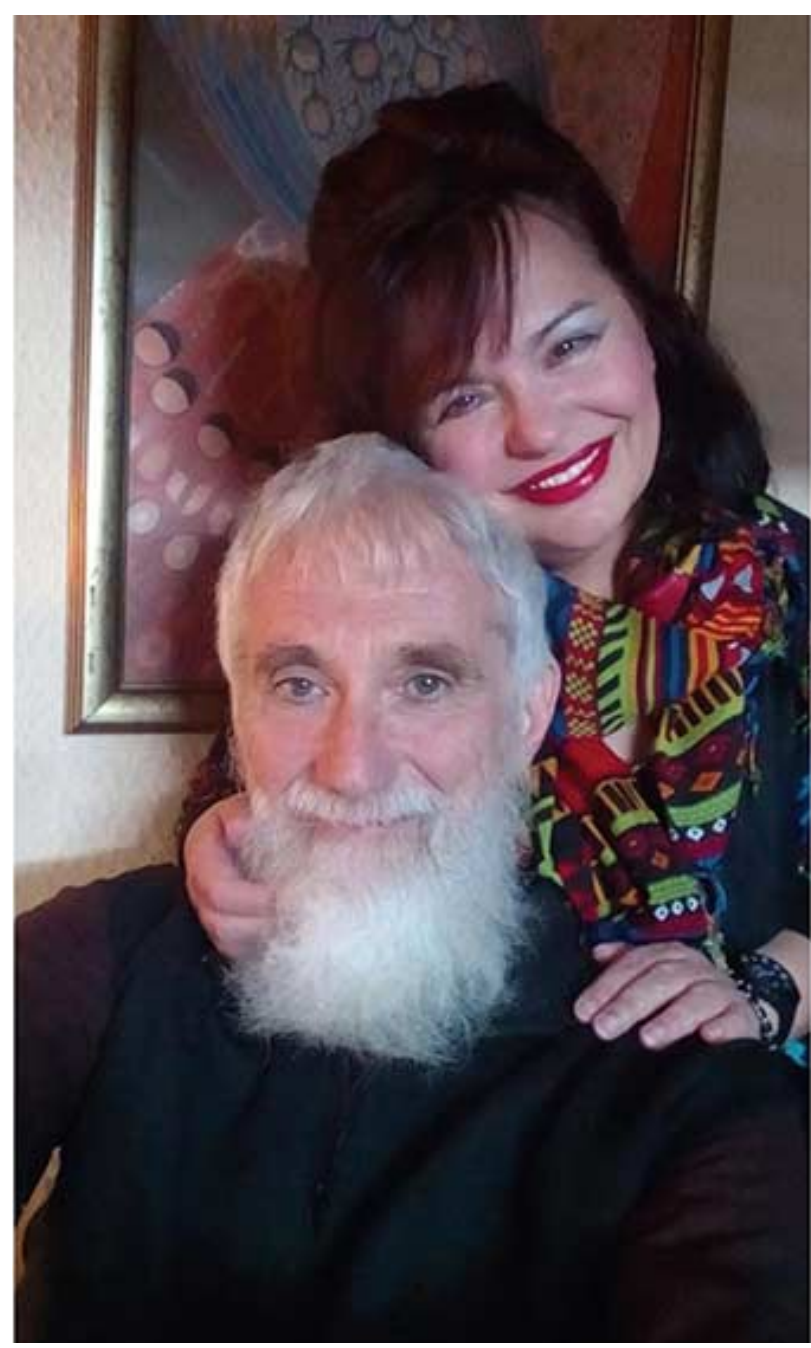

Figure 1: Marina Hughson with her husband John, November, 2019. 


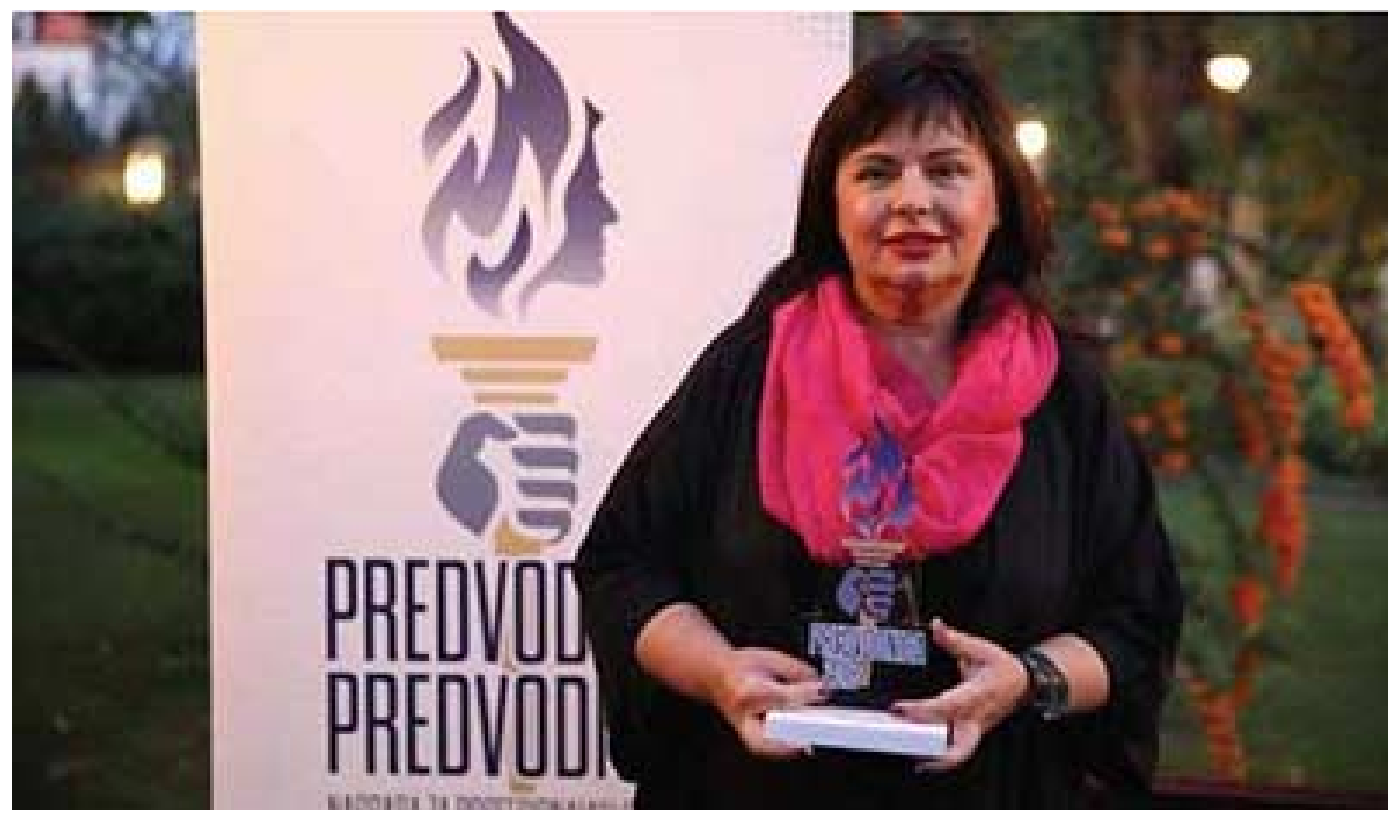

Figure 2: Receiving the Fulbright award in Belgrade in 2018.

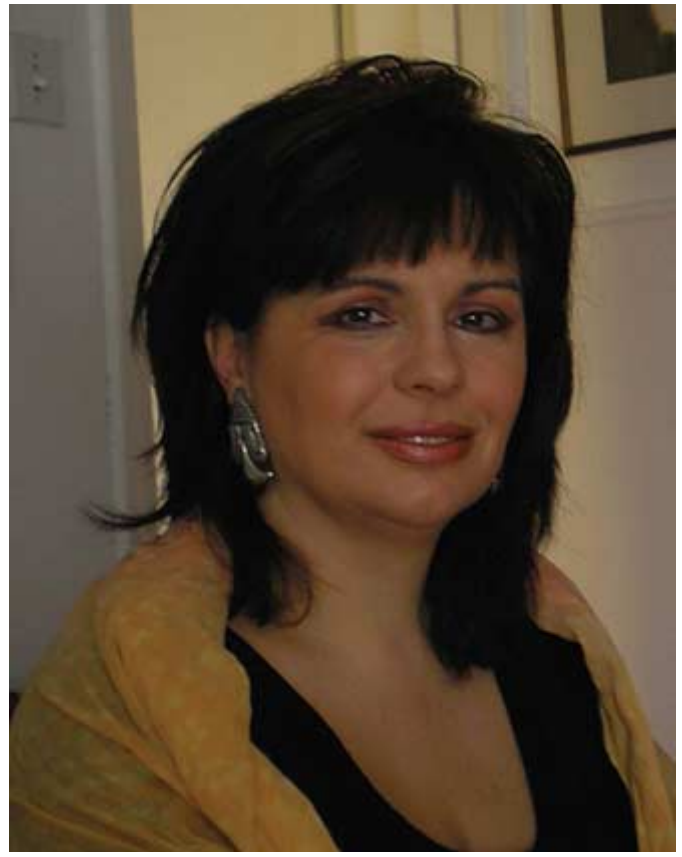

Figure 3: Marina on her $50^{\text {th }}$ birthday.

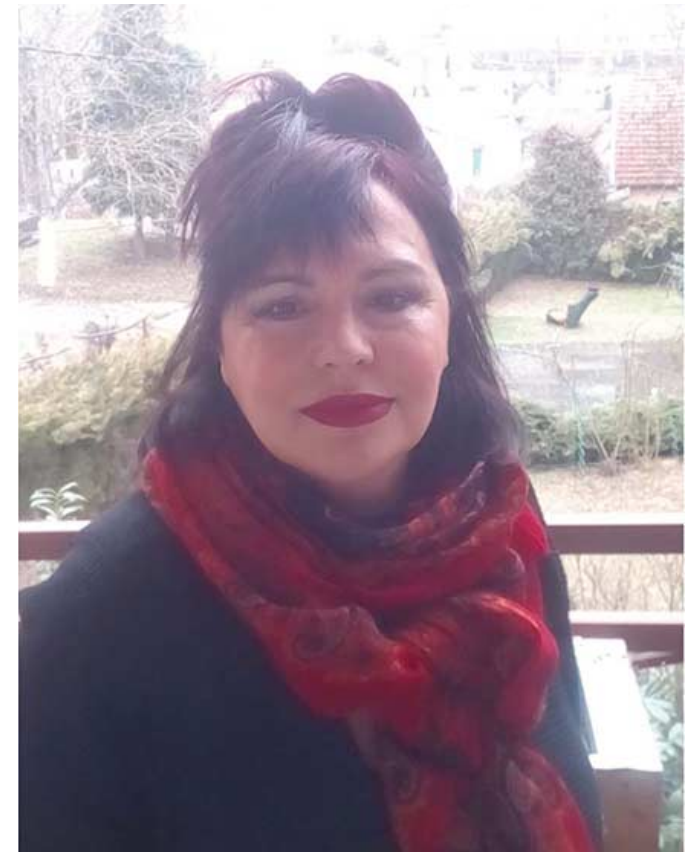

Figure 4: Marina on the terrace at home in Vrdnik February, 2019. 


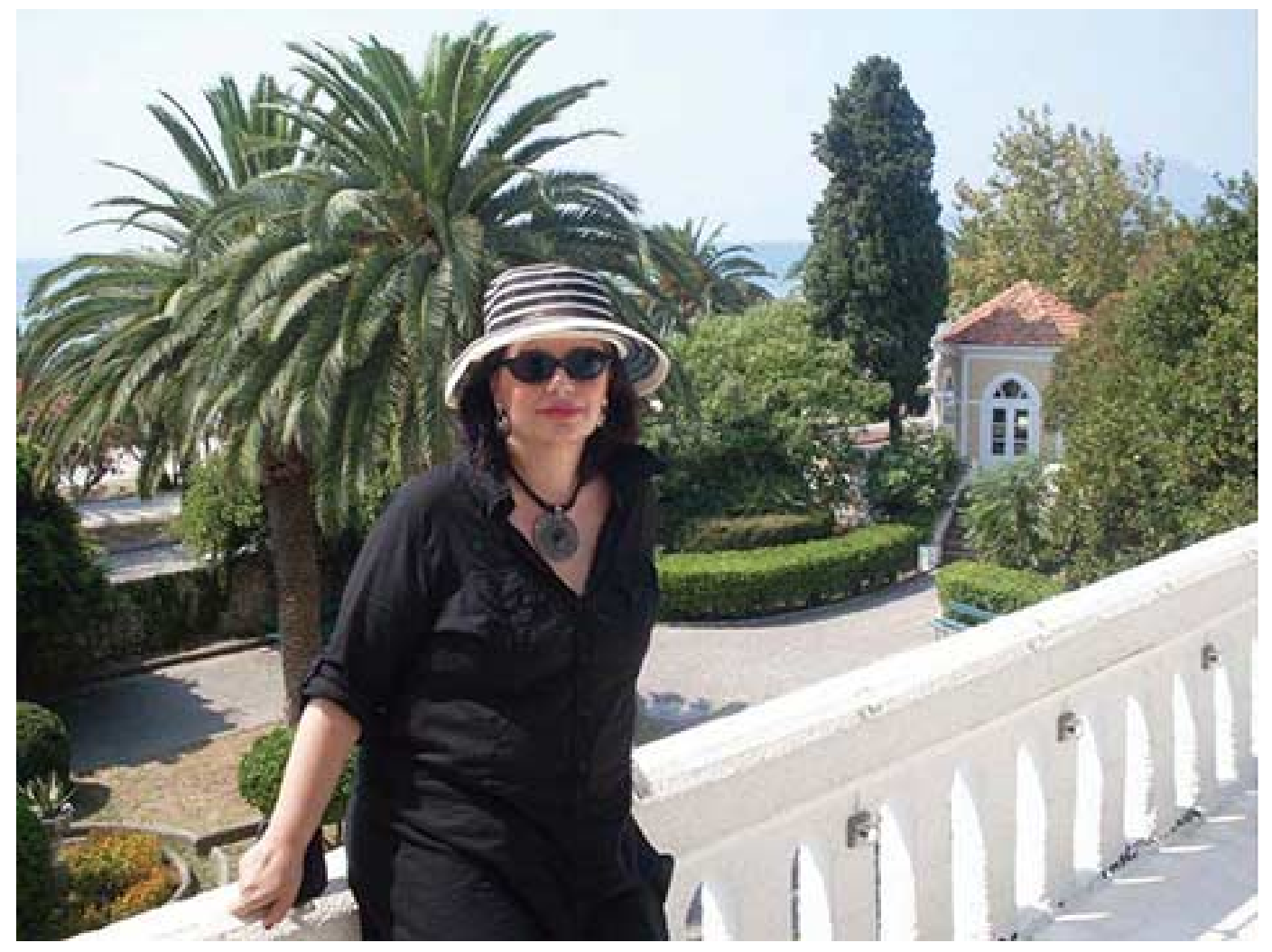

Figure 5: Marina loved her hats. On summer holiday in Bar, Crna Gora.

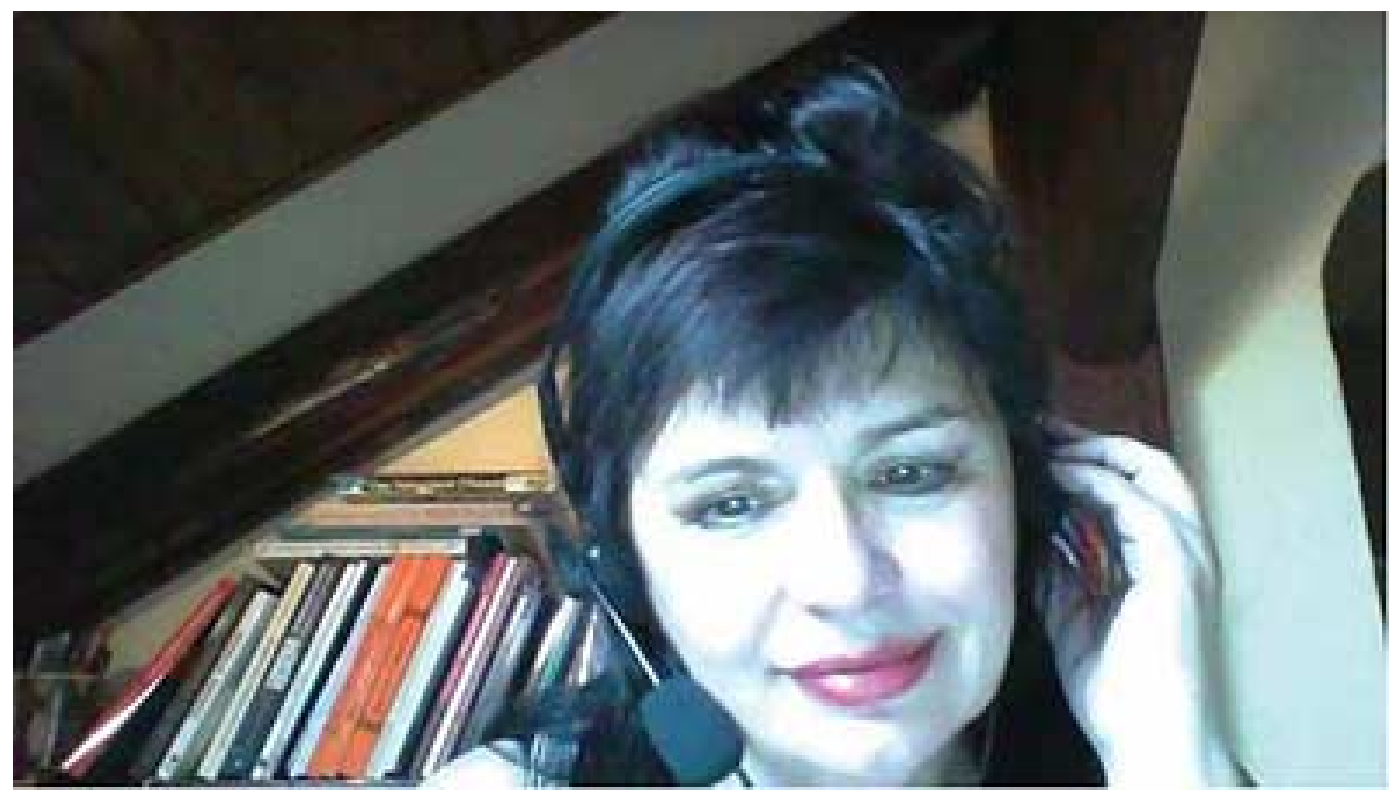

Figure 6: During a skype conversation 2018. 


\section{$\diamond$ Notes}

1. Svenka Savić, Vesna Šijački, Katarina Krajnović, eds., Deset godina Godišnjeg priznanja u oblasti ravnopravnosti polova (2003-2013): Životne price nagrađenih [Ten years of yearly awards in the gender equality domain (2003-2013): Life stories of laureates] (Novi Sad: Zavod za ravnopravnost polova i udruženje građana "Ženske studije i istraživanja," 2014), 220.

2. A selected bibliography of list of Marina Hughson's scholarly works can be found here: https://independent.academia.edu/MarinaHughson?fbclid=IwAR0Z5ZKutjxiexfp13XMi V2Ovc2Pq2fm9d5yKYbj_yG9eOmd3Ppt91EMrLQ (accessed 27 June 2020).

3. Marina Blagojević, Žene izvan kruga: Profesija i porodica [Women outside the circle: Profession and family] (Beograd: ISIFF, 1991).

4. Marina Blagojević, Roditeljstvo i fertilitet: Srbija 90-tih [Parenthood and fertility: Serbia in the 1990s] (Beograd: ISIFF, 1997).

5. Marina Blagojević, ed., Mapiranje mizoginije u Srbiji: diskursi i prakse [Mapping Mysogyny in Serbia: Discourses and Practice] vols. 1 and 2 (Beograd: Asocijacija za žensku inicijativu, 2000; 2005).

6. The Informative-Documentary (INDOC) Center began as a project of the Center for Women's Studies (WSC) in 1997 and was established by the Association for Women's Initiatives, which branched off from the WSC in 1998. It now operates as ŽINDOC Centar (WINDOC-Women's InfoDoc Center, https://www.rosalux.rs/bhs/zenski-informaciono-dokumentacioni-treningcentar (accessed 27 June 2020).

7. Marina Blagojević Hughson, Sutra je bilo juče: prilog društvenoj istoriji žena u polovini 20. veka $u$ Jugoslaviji [Tomorrow was yesterday: A contribution to the social history of women in the second half of the $20^{\text {th }}$ century in Yugoslavia] (Novi Sad: Zavod za ravnopravnost polova, 2015).

8. Marina Blagojević Hughson, Poluperiferija i rod: pobuna konteksta [Semiperiphery and gender: A rebellion of context] (Beograd: IKSI, 2015), 41.

9. Sekcija za feministička istraživanja i kritičke studije maskuliniteta (Section for feminist research and critical studies of masculinities, SEFEM), is a non-governmental academic organization founded in 2012 and headed by Marina Hughson from 2014-2018. See www.sefem.org (accessed 27 June 2020). 